Proceedings

\title{
Membrane Stabilization, Albumin Denaturation, Protease Inhibition, and Antioxidant Activity as Possible Mechanisms for the Anti-Inflammatory Effects of Flavonoid-Rich Extract of Peltophorum pterocarpum (DC.) K.Heyne (FREPP) Stem Bark ${ }^{+}$
}

\author{
Emmanuel Sunday Okeke 1,2,3 , Osmund Chukwuma Enechi ${ }^{1}$ and Ndidi Ethel Nkwoemeka ${ }^{2}$ \\ 1 Department of Biochemistry, University of Nigeria, Nsukka, Enugu State, Nigeria; \\ osmundcenechi@gmail.com \\ 2 Natural Science Unit, School of General Studies, University of Nigeria, Nsukka, Enugu State, Nigeria; \\ ndidi.nkwoemeka@unn.edu.ng \\ 3 School of the Environment and Safety Engineering, Jiangsu University, Zhenjiang 212013, China \\ * Correspondence: emmanuel.okeke@unn.edu.ng; Tel.: +234-803-527-7554 \\ + Presented at the 1st International e-Conference on Antioxidants in Health and Disease, 01-15 December \\ 2020; Available online: https://cahd2020.sciforum.net/.
}

Published: 30 November 2020

\begin{abstract}
In view of the rising global death rate associated with inflammatory diseases, a costfriendly, more effective and safer drug with lesser side effect is needed. The aim of this study was to evaluate membrane stabilization, albumin denaturation, protease inhibition and antioxidant activities as possible mechanisms for the anti-inflammatory effects observed in stem-bark of flavonoid-rich extract of Peltophorum pterocarpum (FREPP). The antioxidant activities were assessed using three various assays hydrogen peroxide, Nitric oxide (NO) and 2,2-diphenyl-1-picrylhydrazyl (DPPH) scavenging activities. The mechanisms for the anti-inflammatory effect of FREPP was determined by membrane stabilization models, test of albumin denaturation, protease inhibitor assay, while the total flavonoid was examined using the aluminium chloride colorimetric test. The ability of FREPP to inhibit membrane lyses of RBC was used to evaluate the anti-inflammatory activity. At $0.1,0.4,0.8 \mathrm{mg} / \mathrm{mL}$, FREPP inhibited hypotonicity-induced haemolysis by $61.03 \%$, $76.84 \%$ and $83.84 \%$ respectively. FREPP was effective in inhibiting albumin denaturation in a concentration dependent manner having the highest inhibition of $69.89 \%$ at $50 \mu \mathrm{g} / \mathrm{mL}$. Protease activity was significantly $(p<0.05)$ reduced across varying concentrations as against the control. It can be inferred from these results that FREPP has antioxidant and anti-inflammatory activities and the mechanisms of the activity may be attributed to its richness in flavonoids known to inhibit lysis of the membrane, albumin denaturation and protease activity.
\end{abstract}

Keywords: Peltophorum pterocarpum; antioxidant; anti-inflammatory; flavonoid; membrane stabilization; albumin denaturation

\section{Introduction}

Inflammation is considered as a protective mechanism employed to eliminate harmful stimuli such as pathogens, damaged cells or irritants thereby initiating the healing process in the body [1]. The early phase of inflammation is characterized by the production of reactive oxygen species (ROS) 
The 1st International Electronic Conference on Antioxidants in Health and Disease, 1-15 December 2020 and the recruitment of inflammatory mediators to the site of injury. When the production of ROS outweighs the neutralization mechanism by antioxidants, oxidative stress is bound to occur [2]. Oxidative stress is implicated during inflammatory processes. The prolonged release of inflammatory mediators can provoke oxidative stress leading to chronic inflammatory diseases. Oxidative stress results in gene expression of pro-inflammatory mediators and oxidative inactivation of antiproteinases. Previous studies have shown that medicinal plants having both antioxidant and antiinflammatory potentials can mitigate against oxidative stress and improve immune function [3]. One of such plants with both antioxidative and anti-inflammatory properties is Peltophorum pterocarpum (DC.) Baker ex Heyne. It is a specie of Peltophorum in the family of Fabaceae. It is also called yellowflamboyant. The bark has been reported to be used in the treatment of pains and management of sores [4]. The infusion of P. pterocarpum stem is used in preparing tooth powder, aqueous extracts of both bark and leaf of $P$. pterocarpum were found to exhibit antioxidant activity against DPPH radical [6]. The presence of flavonoids in these plant parts may be responsible for exhibiting this activity [7]. Due to the limitations posed by existing and mostly synthetic agents, the search for alternative therapies from nature has received much attention recently [8]. Interestingly, safer and more effective drugs have been developed from medicinal plants on the basis of their ethnomedicinal importance [9].

\section{Materials and Methods}

\subsection{Plant Materials}

Freshly collected stem-bark of Peltophorum pterocarpum was gotten within the school premises of the University of Nigeria, Nsukka, Enugu State, Nigeria in 24 March 2019 at the time this research was carried out. The stem-bark was authenticated by Mr. A. O. Ozioko of the International Centre for Ethnomedicine and Drug production (InterCEED), Nsukka Nigeria. Voucher specimen of the plant with No. INTERCEED/076 was deposited at the InterCEED Herbarium.

\subsection{Chemicals and Reagents:}

Chemicals utilized for this study were of the analytical grade and products of May and Baker England, British Drug House (BDH) England, Fluka Germany, Burgoyne, India, Harkin and Williams, England and Sigma Aldrich.

\subsection{Preparation of Plant Material}

The plant was collected, washed, cut into small sizes and shade-dried. The dried stem-bark was pulverized into the powdered form using a mechanical grinder. A weighed quantity (1000 g) was macerated in $3.5 \mathrm{~L}$ absolute ethanol using a maceration flask. It was allowed to stand for $72 \mathrm{~h}$ with frequent stirring, and then filtered into a flat-bottomed flask with the aid of a muslin cloth. Whatman No 1 filter paper was used for further filtration. A rotary evaporator was used to concentrate the filtrate at a temperature of $45{ }^{\circ} \mathrm{C}$ to obtain the crude ethanol extract. The concentrated extract was stored at a temperature of $2-4{ }^{\circ} \mathrm{C}$ in a labeled sterile bottle in the refrigerator.

\subsection{Preparation of Flavonoid-Rich Extract}

This was done using the method previously described by Chu et al. [10]. Crude extract ( $3 \mathrm{~g})$ was dissolved in $20 \mathrm{~mL}$ of $10 \% \mathrm{H}_{2} \mathrm{SO}_{4}$ in a small flask. This was hydrolysed by heating on a water bath for $30 \mathrm{~min}$ at $100{ }^{\circ} \mathrm{C}$. The mixture was placed on ice for $15 \mathrm{~min}$, so as to allow the precipitation of the flavonoids aglycones. The cooled solution was filtered and the filtrate (flavonoid aglycone mixture) was dissolved in $50 \mathrm{~mL}$ of warm $95 \%$ ethanol $\left(50^{\circ} \mathrm{C}\right)$. The resulting solution was again filtered into $100 \mathrm{~mL}$ volumetric flask which was made up to the mark with $95 \%$ ethanol. The filtrate collected was 
The 1st International Electronic Conference on Antioxidants in Health and Disease, 1-15 December 2020 concentrated to dryness using a rotary evaporator. The procedure was repeated several times to obtain enough quantity for the study.

\subsection{Ethical Clearance}

Ethical clearance and approval for the conducive experimental conditions and humane use and handling of blood samples from human subject were given by the ethical committee of the Department of Biochemistry, University of Nigeria Nsukka (with approval numberUN/BCH/1872). Informed consent was obtained from all study subjects.

\subsection{Effect of the Flavonoid-Rich Extract of Peltophorum pterocarpum Stem-Bark on Hypotonicity-Induced Hemolysis of Human Red Blood Cells (HRBC)}

The method of Oyedepo and Femurewa [11], with slight modification was used.

\subsection{Preparation of Human Red Blood Cells Suspension}

Blood sample $(3 \mathrm{~mL})$ obtained from a healthy volunteer was placed into an EDTA bottle, centrifuged at $3000 \mathrm{rpm}$ for $10 \mathrm{~min}$ and washed three times with an equal volume of normal saline. The blood volume was measured and reconstituted as a $40 \%(v / v)$ suspension with normal saline.

\subsection{Procedure}

The extract and indomethacin used were dissolved in distilled water which served as the hypotonic solution. An aliquot $(1 \mathrm{~mL})$ of varying concentrations of the extract $(0.1,0.2,0.4,0.6,0.8$ $\mathrm{mg} / \mathrm{mL}$ ) was put into each of a set of five test tubes. Another tube contained $1 \mathrm{~mL}$ of $0.6 \mathrm{mg} / \mathrm{mL}$ indomethacin. The contents of the respective tubes were made up to $4.9 \mathrm{~mL}$ with the distilled water. Two control tubes were used for this test. A control tube contained $4.9 \mathrm{~mL}$ of the vehicle while another contained $4.9 \mathrm{~mL}$ of normal saline (isotonic solution). HRBCs suspension $(0.1 \mathrm{~mL})$ was added to each tube, and after gentle mixing, the mixtures were incubated for $1 \mathrm{~h}$ at $37^{\circ} \mathrm{C}$. After incubation, the reaction mixture for each tube was centrifuged at $3000 \times \mathrm{g}$ for $10 \mathrm{~min}$ and the absorbance of the supernatant measured at $540 \mathrm{~nm}$ using a spectrophotometer. The tests were carried out in triplicates. The reaction media containing $1 \mathrm{~mL}$ varying concentrations of extract or indomethacin made up to $5.0 \mathrm{~mL}$ with normal saline, without HRBCs suspension were used as the respective blank for each test. The blank for the control tubes contained normal saline without HRBCs suspension. The percentage inhibition of haemolysis was calculated using the relation below:

$$
\% \text { Inhibition of haemolysis }=100 A=100\left(1-\frac{O D 2-O D 1}{O D 3-O D 1}\right)
$$

where $O D 1=$ Absorbance of control I (isotonic solution), OD2 = Absorbance of test sample, OD3 = Absorbance of control II (hypotonic solution)

\subsection{Effect of the Flavonoid-Rich Extract of Peltophorum pterocarpum Stem Bark on Albumin Denaturation}

The method of Mizushin and Kobyashi [12] with minor modifications was used. The reaction mixture consisted of test extract and 1\% aqueous solution of bovine albumin fraction; $\mathrm{pH}$ of the reaction mixture was adjusted using a small amount of $\mathrm{HCl}$ at $37^{\circ} \mathrm{C}$. The extract sample was incubated at $37^{\circ} \mathrm{C}$ for $20 \mathrm{~min}$ and then at $51^{\circ} \mathrm{C}$ for $20 \mathrm{~min}$, after cooling the samples, the turbidity was read spectrophotometrically at $660 \mathrm{~nm}$. The experiment was performed in triplicate. Percentage inhibition of protein denaturation was calculated as follows:

Percentage inhibition $(\%)=[\{$ Abs control - Abs sample $\} /$ Abs control $] \times 100$

\subsection{Effect of Flavonoid-Rich Extract of Peltophorum pterocarpum Stem Bark on Protease Activity}


The 1st International Electronic Conference on Antioxidants in Health and Disease, 1-15 December 2020

The test was performed according to the method described by 11.13 with minor modification. The reaction mixture $(2 \mathrm{~mL})$ was containing $0.06 \mathrm{mg}$ trypsin, $20 \mathrm{Mm}$ Tris $\mathrm{HCl}$ buffer (pH 7.4) and 1 $\mathrm{mL}$ test sample of different concentrations $(0.1-0.5 \mu \mathrm{g} / \mathrm{mL})$. The mixture was incubated for an additional $20 \mathrm{~min}$. $2 \mathrm{~mL}$ of $70 \%$ perchloric acid was added to arrest the reaction. The cloudy suspension was centrifuged and the absorbance of the supernatant was read at $210 \mathrm{~nm}$ against buffer as blank. The experiment was performed in triplicate. The percentage inhibition of protease inhibitor activity was calculated as:

Percentage inhibition $(\%)=[\{$ Abs control - Abs sample $\} /$ Abs control $] \times 100$

\subsection{Hydrogen Peroxide Scavenging Activity of Extract of P. pterocarpum Stem Bark}

This activity of the plant extract was evaluated by the method of Ruch et al. [14]. $80 \mu \mathrm{L}$ of the aqueous plant extract was added to $150 \mu \mathrm{L}$ of $4 \mathrm{~mm}$ hydrogen peroxide solution prepared in phosphate buffer (0.1 M, pH 7.4). This was incubated for $10 \mathrm{~min}$, and the absorbance was read at $230 \mathrm{~nm}$.

\subsection{Nitric Oxide (NO) Scavenging Activity of Extract of P. pterocarpum Stem Bark}

Nitric oxide scavenging activity was by the method of Garrat [15], the sample was determined by adding $400 \mu \mathrm{L}$ of $100 \mathrm{mM}$ sodium nitroprusside, $100 \mu \mathrm{L}$ of PBS (pH 7.4) and $100 \mu \mathrm{L}$ of different concentrations of the plant extract. The reaction mixture was incubation at $25^{\circ} \mathrm{C}$ for $150 \mathrm{~min}$. To 0.5 $\mathrm{mL}$ of above solution, $0.5 \mathrm{~mL}$ of Griess reagent was added $(0.1 \mathrm{~mL}$ of sulfanilic acid and $200 \mu \mathrm{L})$ naphthyl ethlenediamine dichloride $(0.1 \% \mathrm{w} / \mathrm{v}))$. This was incubated at room temperature for $30 \mathrm{~min}$, and finally absorbance was read at $540 \mathrm{~nm}$. All the reactions were performed in triplicates and their percentage inhibition was calculated by the formula:

$$
\text { Percentage inhibition }(\%)=[\{\text { Abs control }- \text { Abs sample }\} / \text { Abs control }] \times 100
$$

\subsection{Determination of DPPH Radical Scavenging Activity of Extract of P. pterocarpum Stem Bark}

DPPH (1,1-diphnyl-2-picrylhydrazyl) was used to determine the free radical scavenging activity of the extract by method of the Bloiss [16]. DPPH radical was prepared by dissolving $0.0024 \mathrm{~g}$ DPPH in $100 \mathrm{~mL}$ methanol (purple). To $1.0 \mathrm{~mL}$ of different concentrations from $0.1-0.6 \mu \mathrm{g} / \mathrm{mL}, 1.0 \mathrm{~mL}$ DPPH was added and left in the dark for $20 \mathrm{~min}$, and then the absorbance was read at $517 \mathrm{~nm}$. Ascorbic acid was used as a reference drug and the percentage inhibition of DPPH formation was calculated as:

Percentage inhibition $(\%)=[\{$ Abs control - Abs sample $\} /$ Abs control $] \times 100$

\subsection{Statistical Analysis}

The data obtained were analysed using a one-way analysis of variance (ANOVA) in Statistical Product and Service Solution (SPSS) version 22.0 and presented as Mean \pm SD. Mean values with $p<$ 0.05 were accepted as significant.

\section{Results and Discussion}

In Table 1, the FREPP stem-bark and indomethacin in a concentration-dependent manner significantly $(p<0.05)$ inhibited the lysis of the human erythrocyte membrane which was induced by hypotonic solution when compared to the control. The flavonoid-rich extract inhibited hypotonic solution induced lyses of HRBCs membrane. The preponderance of polyunsaturated fatty acids (PUFAs) within the RBCs membrane makes the cells enormously prone to oxidative harm [17] leading to hemolysis through which hemoglobin and different internal cellular components are released. Injurious agents such as hypotonic solution, heat, etc can lead to lyses of the RBC membrane. The FREPP stem-bark at various concentrations significantly $(p<0.05)$ prevented the lysis of the HRBC membrane. The results indicated the capacity of FREPP to inhibit haemolysis. The inhibition of RBC membrane lyses is a measure of the anti-inflammatory activity [18,19]. The ability of the 
The 1st International Electronic Conference on Antioxidants in Health and Disease, 1-15 December 2020

FREPP to stabilize the erythrocyte membranes implies that it might stabilize lysosomal membranes as well. Stabilizing the lysosomal membrane is very crucial regulating inflammatory responses which help to prevent the release of lysosomal constituents of activated leukocytes (such as bactericidal enzymes and proteases) which upon extracellular release lead to further tissue inflammation and consequently leads to tissue damage [20-22]. The result thus provides evidence for membrane stabilization as a potential mechanism of the anti-inflammatory effect of flavonoid-rich extract of $P$. pterocarpum stem-bark.

Table 1. Inhibition of hypotonicity-induced hemolysis of human RBC cells by flavonoid-rich extract of P. pterocarpum stem-bark on hypotonicity-induced hemolysis of HRBC.

\begin{tabular}{|c|c|c|c|c|c|c|}
\hline \multirow[b]{2}{*}{ Treatment } & \multirow[b]{2}{*}{$\begin{array}{c}\text { Concentration } \\
(\mathrm{mg} / \mathrm{mL})\end{array}$} & \multicolumn{2}{|c|}{$\mathrm{OD}_{540 \mathrm{~nm}}$} & \multicolumn{3}{|c|}{ Difference in OD Values } \\
\hline & & $\begin{array}{c}\text { Hypertonic } \\
\text { Solution }\left(\mathrm{OD}_{3}\right)\end{array}$ & $\begin{array}{c}\text { Hypotonic } \\
\left(\mathrm{OD}_{2}\right)\end{array}$ & $\begin{array}{c}\text { Isotonic } \\
\left(\mathrm{OD}_{1}\right)\end{array}$ & $\begin{array}{l}\left(\mathrm{OD}_{2-}\right. \\
\left.\mathrm{OD}_{1}\right)\end{array}$ & $\begin{array}{l}\text { \% Inhibition } \\
\text { of Haemolysis }\end{array}$ \\
\hline Control & - & $0.429 \pm 0.002$ & - & - & - & - \\
\hline Control & - & - & - & $\begin{array}{c}0.100 \pm \\
0.001\end{array}$ & - & - \\
\hline \multirow[t]{4}{*}{ Extract } & 0.1 & - & $0.228 \pm 0.001 \mathrm{~g}$ & - & 0.128 & 61.03 \\
\hline & 0.2 & - & $0.197 \pm 0.002$ e & - & 0.09 & 70.52 \\
\hline & 0.4 & - & $0.176 \pm 0.001^{\mathrm{d}}$ & - & 0.076 & 76.84 \\
\hline & 0.6 & - & $0.167 \pm 0.001^{c}$ & - & 0.067 & 79.64 \\
\hline \multirow[t]{2}{*}{ Indomethacin } & 0.8 & - & $0.153 \pm 0.003^{b}$ & - & 0.053 & 83.84 \\
\hline & 0.4 & - & $0.218 \pm 0.001^{\mathrm{f}}$ & - & 0.118 & 64.11 \\
\hline
\end{tabular}

Values are Mean \pm Standard Deviation, $\mathrm{n}=3$, values with superscripts $\mathrm{b}, \mathrm{c}, \mathrm{d}, \mathrm{e}, \mathrm{f}, \mathrm{g}$ are considered significant $(p<0.05)$.

Table 2 shows the effect of flavonoid-rich extract of P. pterocarpum stem bark on albumin denaturation. The FREPP stem-bark was effective in inhibiting albumin denaturation. Varying concentrations of the plant extract significantly $(p<0.05)$ inhibited the denaturation of albumin when compared to the control group. Diclofenac sodium showed a similar trend. The inhibition by the extract is concentration-dependent with $10 \mu \mathrm{g} / \mathrm{mL}$ having an inhibition of $6.95 \%$ and $50 \mu \mathrm{g} / \mathrm{mL}$ with the highest inhibition of $69.89 \%$. Protein denaturation is a process in which proteins lose their structure by application of external stress or compounds and is seen as a marker for inflammatory and arthritic diseases [23]. The ability of flavonoid-rich extract of P. pterocarpum stem bark to inhibit protein denaturation also lend credence to its anti-inflammatory activity. The flavonoid-rich extract was effective in inhibiting albumin denaturation.

Table 2. Effect of flavonoid-rich extract of P. pterocarpum stem bark on albumin denaturation.

\begin{tabular}{cccc}
\hline Treatment & Concentration $(\boldsymbol{\mu g} / \mathbf{m L})$ & O.D $(660 \mathbf{~ n m})$ & \% Inhibition \\
\hline Control & - & $0.518 \pm 0.006 \mathrm{~g}$ & - \\
Extract & 10 & $0.482 \pm 0.001 \mathrm{f}$ & 6.95 \\
& 20 & $0.359 \pm 0.001 \mathrm{e}$ & 30.70 \\
& 30 & $0.195 \pm 0.002^{\mathrm{c}}$ & 62.36 \\
& 40 & $0.165 \pm 0.002^{\mathrm{b}}$ & 68.15 \\
& 50 & $0.156 \pm 0.001 \mathrm{a}$ & 69.89 \\
(Diclofenac Sodium) & 100 & $0.276 \pm 0.004 \mathrm{~d}$ & 46.72 \\
\hline
\end{tabular}

Values are Mean \pm Standard Deviation, $\mathrm{n}=3$, values with superscripts $\mathrm{a}, \mathrm{b}, \mathrm{c}, \mathrm{d}, \mathrm{e}, \mathrm{f}, \mathrm{g}$ are considered significant $(p<0.05)$.

Table 3 shows the protease activity of flavonoid-rich extract of Peltophorum pterocarpum stem bark. The stem bark inhibited significantly $(p<0.05)$ protease activity at different concentrations when compared to the control. The standard drug showed similar results (Table 3). Protease inhibitors play 
The 1st International Electronic Conference on Antioxidants in Health and Disease, 1-15 December 2020 important role for the better interpretation of basic principle of protein interaction. Proteolytic enzymes such as bromelain, papain, pancreatin, trypsin, chymotrypsin and rutin are essential regulators and modulators of inflammatory responses. Neutrophils are known to be a rich source of serine protease and are localized at lysosomes. It has been previously reported that leukocytes protease plays important role in the development of tissue damage during inflammatory reactions and significant level of protection was provided by protease inhibitors [24]. Different concentrations of extract significantly $(p<0.05)$ inhibited protease activity at different concentrations. This could be as a result of its high flavonoid content. This assay provides another evidence for its promising antiinflammatory properties.

Table 3. Effect of flavonoid-rich extract of P. pterocarpum stem bark on protease activity.

\begin{tabular}{cccc}
\hline Treatment & Concentration $(\boldsymbol{\mu g} / \mathbf{m L})$ & Absorbance $(\text { O.D })_{210 n m}$ & \% Inhibition \\
\hline Control & - & $0.300 \pm 0.001 \mathrm{~g}$ & - \\
Extract & 10 & $0.923 \pm 0.001^{\mathrm{f}}$ & 29.00 \\
& 20 & $0.876 \pm 0.001^{\mathrm{e}}$ & 32.61 \\
& 30 & $0.777 \pm 0.002^{\mathrm{c}}$ & 40.15 \\
& 50 & $0.750 \pm 0.002^{\mathrm{b}}$ & 42.30 \\
& 100 & $0.735 \pm 0.003^{\mathrm{a}}$ & 43.46 \\
& 10 & $0.808 \pm 0.005^{\mathrm{d}}$ & 37.85 \\
\hline
\end{tabular}

Values are Mean \pm Standard Deviation, $n=3$, values with superscripts $a, b, c, d, e, f, g$ are considered significant $(p<0.05)$.

Table 4 showed that different concentrations of the plant extract $(10,20,30,40$ and $60 \mu \mathrm{g} / \mathrm{mL})$ significantly $(p<0.05)$ inhibited the oxidative stress resulting from hydrogen peroxide $\left(\mathrm{H}_{2} \mathrm{O}_{2}\right)$ radicals when compared to the control. As the concentration of the extract $(10,20,30,40,60 \mu \mathrm{g} / \mathrm{mL})$ increases, the percentage inhibition increased having $23.8 \%, 44.0 \%, 57.8 \%, 73.1 \%, 86.2 \%$, respectively, and ascorbic acid caused a percentage inhibition of $80.0 \% . \mathrm{H}_{2} \mathrm{O}_{2}$ is known for its ability to penetrate into biological membranes. $\mathrm{H}_{2} \mathrm{O}_{2}$ itself is not very reactive, but its hydroxyl radicals are very toxic to cells. Scavenging of $\mathrm{H}_{2} \mathrm{O}_{2}$ by the extract may be attributed to the high concentration of flavonoids present in the extract which can donate electrons to $\mathrm{H}_{2} \mathrm{O}_{2}$, thus neutralizing $\mathrm{H}_{2} \mathrm{O}_{2}$ to water $\left(\mathrm{H}_{2} \mathrm{O}\right)$. The results show that the FREPP had potent $\mathrm{H}_{2} \mathrm{O}_{2}$ scavenging activity which may be due to the flavonoid. The results show an excellent inhibition percentage in a concentration-dependent manner.

Table 4. $\mathrm{H}_{2} \mathrm{O}_{2}$ scavenging activity of flavonoid-rich extract of $P$. pterocarpum.

\begin{tabular}{cccc}
\hline Treatment & Concentration $(\boldsymbol{\mu g} / \mathbf{m L})$ & O.D $(\mathbf{2 3 0} \mathbf{n m})$ & \% Inhibition \\
\hline Control & - & $1.804 \pm 0.002 \mathrm{~g}$ & \\
Extract 1 & 10 & $1.374 \pm 0.005^{\mathrm{f}}$ & 23.8 \\
Extract 2 & 20 & $1.010 \pm 0.003^{\mathrm{e}}$ & 44.0 \\
Extract 3 & 30 & $0.764 \pm 0.005^{\mathrm{d}}$ & 57.6 \\
Extract 4 & 40 & $0.486 \pm 0.003^{\mathrm{c}}$ & 73.1 \\
Extract 5 & 60 & $0.249 \pm 0.002^{\mathrm{a}}$ & 86.2 \\
(Ascorbic Acid) & 100 & $0.361 \pm 0.002^{\mathrm{b}}$ & 80.0 \\
\hline
\end{tabular}

Values are Mean \pm Standard Deviation, $\mathrm{n}=3$, values with superscripts $\mathrm{a}, \mathrm{b}, \mathrm{c}, \mathrm{d}, \mathrm{e}, \mathrm{f}, \mathrm{g}$ are considered significant $(p<0.05)$.

Table 5 shows that the plant extract at different concentrations $(10,20,30,40,60 \mu \mathrm{g} / \mathrm{mL})$ in a concentration-dependent manner inhibited significantly $(p<0.05)$ the oxidative stress caused by DPPH radicals when compared to the control. The free-radical scavenging activity by DPPH is a widely used method to evaluate the free radical scavenging ability in various plant species in short period [25]. The extract showed an excellent scavenging activity compared to ascorbic acid. The 
The 1st International Electronic Conference on Antioxidants in Health and Disease, 1-15 December 2020 results are comparable to other free radical scavenging methods [26]. The flavonoid-rich extract and ascorbic acid neutralized the free radical character of DPPH by transferring either electrons or hydrogen atoms to DPPH [27], thereby changing the colour from purple to the yellow colored stable diamagnetic molecule diphenylpicrylhydrazine.

Table 5. DPPH Scavenging activity of flavonoid-rich extract of $P$. pterocarpum.

\begin{tabular}{cccc}
\hline Treatment & Concentration $(\boldsymbol{\mu g} / \mathbf{m L})$ & O.D $(\mathbf{5 1 7} \mathbf{~ n m})$ & \% Inhibition \\
\hline Control & - & $0.218 \pm 0.003^{\mathrm{e}}$ & \\
Extract 1 & 10 & $0.164 \pm 0.0044^{\mathrm{d}}$ & 24.8 \\
Extract 2 & 20 & $0.118 \pm 0.002^{\mathrm{c}}$ & 45.9 \\
Extract 3 & 30 & $0.110 \pm 0.002^{\mathrm{b}}$ & 49.5 \\
Extract 4 & 40 & $0.094 \pm 0.002^{\mathrm{a}}$ & 56.9 \\
Extract 5 & 60 & $0.089 \pm 0.003^{\mathrm{a}}$ & 59.2 \\
(Ascorbic Acid) & 100 & $0.092 \pm 0.005^{\mathrm{a}}$ & 57.8
\end{tabular}

Values are Mean \pm Standard Deviation, $n=3$, Superscripts $a, b, c, d$, e considered significant $(p<0.05)$.

The degree of discolouration indicated the scavenging potential of the flavonoid-rich extract of P. pterocarpum stem bark in terms of hydrogen donating ability [28].

Table 6 showed that the plant extract at different concentrations $(10,20,30,40,60 \mu \mathrm{g} / \mathrm{mL})$ in a concentration-dependent manner inhibited significantly $(p<0.05)$ oxidative stress caused by Nitric oxide (NO) radicals when compared to the control. The percentage inhibition is $20.4 \%, 29.9 \%, 36.2 \%$, $48.8 \%, 49.4 \%$, respectively while ascorbic acid caused a percentage inhibition of $50.9 \%$. The flavonoidrich extract of $P$. pterocarpum exhibited NO scavenging activity leading to the reduction of the nitrite concentration in the assay medium. In the study, the NO scavenging capacity was concentrationdependent with the highest concentration with the most scavenging activity. The ethanol flavonoidrich extract of P. pterocarpum in sodium nitropruside (SNP) solution significantly inhibited $(p<0.05)$ the accumulation of nitrite, a stable oxidation product of NO liberated from SNP in the reaction medium with time compared to ascorbic acid. The toxicity of NO increases when it reacts with superoxide to form the peroxynitrite anion, which is a potential strong oxidant that can decompose to produce $\mathrm{OH}$ and $\mathrm{NO}_{2}$ [29]. The flavonoid-rich extract also exerted significant $\mathrm{H}_{2} \mathrm{O}_{2}$ radical scavenging activity.

Table 6. NO scavenging activity of flavonoid-rich extract of $P$. pterocarpum.

\begin{tabular}{cccc}
\hline Treatment & Concentration $(\boldsymbol{\mu g} / \mathbf{m L})$ & O.D $\mathbf{( 5 4 0 ~} \mathbf{~ m})$ & \% Inhibition \\
\hline Control & - & $1.123 \pm 0.004 \mathrm{~g}$ & \\
Extract 1 & 10 & $0.894 \pm 0.003^{\mathrm{f}}$ & 20.4 \\
Extract 2 & 20 & $0.787 \pm 0.002 \mathrm{e}^{\mathrm{e}}$ & 29.9 \\
Extract 3 & 30 & $0.717 \pm 0.003 \mathrm{~d}$ & 36.2 \\
Extract 4 & 40 & $0.575 \pm 0.003^{\mathrm{c}}$ & 48.8 \\
Extract 5 & 60 & $0.568 \pm 0.003 \mathrm{~b}$ & 49.4 \\
(Gallic Acid) & 100 & $0.551 \pm 0.002 \mathrm{a}$ & 50.9 \\
\hline
\end{tabular}

Values are Mean \pm Standard Deviation, $\mathrm{n}=3$, values with superscripts $\mathrm{a}, \mathrm{b}, \mathrm{c}, \mathrm{d}, \mathrm{e}, \mathrm{f}, \mathrm{g}$ are considered significant $(p<0.05)$.

\section{Conclusions}

The results of the investigations show that the plant extract exhibited significant antioxidant and potent anti-inflammatory effects. The rich flavonoid content of the extract may be responsible for these outcomes. The study provides a scientific basis for the ethnomedicinal claims for the use of this plant in curing inflammatory ailments. 
The 1st International Electronic Conference on Antioxidants in Health and Disease, 1-15 December 2020

Funding: This research received no external funding.

Conflicts of Interest: The authors declare no conflict of interest.

Authors' Declaration: The authors hereby declare that the work presented in this article is original and that any liability for claims relating to the content of this article will be borne by them.

\section{References}

1. Okeke, E.S.; Enechi, O.C.; Nwankwo, N.E.; Nwodo, O.F.C. Evaluation of the Phytochemical Constituents and Anti-Inflammatory Potential of Fagara Zanthoxyloides Root-Bark Using In Vivo and In Vitro Models. Pharmacol Online 2019, 2, 212-224.

2. Reuter, S.; Gupta, S.C.; Chaturvedi, M.M.; Aggarwal, B.B. Oxidative stress, inflammation, and cancer: How are they linked? Free Radic. Biol. Med. 2010, 49, 1603-1616.

3. Ricordi, C.; Garcia-Contreras, M.; Farnetti, S.; Diet and inflammation: Possible effects on immunity, chronic diseases, and life span. J. Am. Coll. Nutr. 2015, 34, 10-13.

4. Sethuraman, M.G.; Sulochana, N.; Kameswaran, L. Anti-inflammatory and antibacterial activity of Peltophorum pterocarpum flowers. Fitoterapia 1984, 55, 177-179.

5. Jain, S.C.; Pancholi, B.; Jain, R. Antimicrobial, free radical scavenging activities and chemical composition of Peltophorum pterocarpum Baker ex K. Heyne stem extract. Der Pharma Chem. 2012, 4, 2073-2079.

6. Ling, L.T.; Palanisamy, U.D. Review: Potential Antioxidants from Tropical Plants. Food Industrial ProcessesMethods; In Tech: Kuala Lumpur, Malaysia, 1999; pp. 64-72.

7. Manaharan, T.; Teng, L.L.; Appleton, D.; Ming, C.H.; Masilamani, T.; Palanisamy, U.D. Antioxidant and antiglycemic potential of Peltophorum pterocarpum plant parts. Food Chem. 2011, 129, 1355-1361.

8. Murugan, R.; Parimelazhagan, T. Comparative evaluation of different extraction methods for antioxidant and anti-inflammatory properties from Osbeckia parvifolia Arn. - An in vitro approach. J. King Saud Univ. Sci. 2014, 26, 267-275.

9. Das, B.; Ferdous, T.; Mahmood, Q.A.; Hannan, J.M.; Bhattacharjee, R.; Das, B.K. Antinociceptive and antiinflammatory activity of the bark extract of Plumeria rubra on laboratory animals. Eur. J. Med. Chem. 2013, 3, 114-126.

10. Sun, J.; Chu, Y.F.; Wu, X.; Liu, R.H. Antioxidant and antiproliferative activities of common fruits. J. Agric. Food Chem. 2002, 50, 7449-7454.

11. Oyedapo, O.O.; Famurewa, A.J. Antiprotease and membrane stabilizing activities of extracts of Fagara zanthoxyloides, Olax subscorpioides and Tetrapleura tetraptera. Int. J. Pharmacol. 1995, 33, 65-69.

12. Mizushima, Y.; Kobayashi, M. Interaction of anti-inflammatory drugs with serum proteins, especially with some biologically active proteins. J. Pharm. Pharmacol. 1968, 20, 169-173.

13. Sakat, S.; Juvekar, A.R.; Gambhire, M.N. In vitro antioxidant and anti-inflammatory activity of methanol extract of Oxalis corniculata Linn. Int. J. Pharm. Pharm. Sci. 2010, 2, 146-155.

14. Ruch, R.J.; Cheng, S.J.; Klaunig, J.E. Prevention of cyto-toxicity and inhibition of intercellular communication by anti-oxidant catechins isolated from Chineese green tea. Carcinogenesis 1989, 10, 10031008.

15. Garrat, D.C.The quantitative analysis of drugs. Champman and Hall. Japana 1964, 3, 456-458.

16. Blois, M.S. Antioxidant determinations by the use of a stable free radical. Nature 1958, 181, 1199-1200.

17. Divya, N.; Nagamani, J.E.; Prabhu, S. Antioxidant and antihemolytic activities of Bombax Ceiba pentandra spike and fruit extracts. Int. J. Pharm. Pharm. Sci. 2012, 4, 311-315.

18. Mounnissamy, V.M.; Kavimani, S.; Balu, V.; Quine, S.D. Evaluation of Anti-inflammatory and Membrane stabilizing property of Ethanol Extract of Cansjera rheedii J. Gmelin (Opiliaceae). Iran J. Pharmacol. Ther. 2007, $6,235-240$.

19. Zohra, M.; Fawzia, A. Hemolytic activity of different herbal extracts used in Algeria. Int. J. Pharm. Sci. Res. 2014, 5, 8495-8494.

20. Cunha, T.M.; Verri, W.A., Jr.; Poole, S.; Parada, C.A.; Cunha, F.Q.; Ferreira, S.H. Pain facilitation by proinflammatory cytokine actions at peripheral nerve terminals. Immun Glial Reg. Pain 2007, 67, 83.

21. Borregaard, N. Neutrophils, from marrow to microbes. Immunity 2010, 33, 657-670. 
The 1st International Electronic Conference on Antioxidants in Health and Disease, 1-15 December 2020

22. Anosike, C.A.; Obidoa, O.; Ezeanyika, L.U. The anti-Inflammatory activity of garden egg (Solanum aethiopicum) on egg albumin-Induced oedema and granuloma tissue formation in rats. Asian Pac. J. Trop. Med. 2012, 5, 62-66.

23. Berbert, A.A.; Kondo, C.R.; Almendra, C.L.; Matsuo, T.; Dichi, I. Supplementation of fish oil and olive oil in patients with rheumatoid arthritis. Nutrition 2005, 21, 131-136.

24. Kajay, T.D.; Shanthi, P.; Sachdanandam, P.; Protein denaturation and white blood cell migration during acute inflammation. J. Med. Plants Res. 2006, 4, 789-795.

25. Mohammad, A.; Ebrahimzadeh, S.F., Nabavi, S.M. Essential oil composition and antioxidant activity of Pterocarya fraxinifoli. Pak. J. Biol. Sci. 2009, 12, 957-963.

26. Gil, M.I.; Tomás-Barberán, F.A.; Hess-Pierce, B.; Holcroft, D.M.; Kader, A.A. Antioxidant activity of pomegranate juice and its relationship with phenolic composition and processing. J. Agric. Food Chem. 2000, $48,4581-4589$.

27. Naik, G.H.; Priyadarsini, K.I.; Satav, J.G.; Banavalikar, M.M.; Sohoni, D.P.; Biyani, M.K.; Mohan, H. Comparative antioxidant activity of individual herbal components used in Ayurvedic medicine. Phytochemistry 2003, 63, 97-104.

28. Mosquera, O.M.; Correa, Y.M.; Buitrago, D.C.; Niño, J. Antioxidant activity of twenty-five plants from Colombian biodiversity. Memorias do Instituto Oswaldo Cruz. 2007, 102, 631-634.

29. Pacher, P.; Beckman, J.S.; Liaudet, L. Nitric oxide and peroxynitrite in health and disease. Physiol. Rev. 2007, $87,315-424$.

Publisher's Note: MDPI stays neutral with regard to jurisdictional claims in published maps and institutional affiliations.

(C) 2020 by the authors. Submitted for possible open access publication under the terms and conditions of the Creative Commons Attribution (CC BY) license (http://creativecommons.org/licenses/by/4.0/). 